\title{
ANALISIS FAKTOR-FAKTOR YANG MEMPENGARUHI PROFITABILITAS PADA BANK UMUM SWASTA NASIONAL DEVISA YANG TERDAFTAR DI BURSA EFEK INDONESIA
}

\author{
Nani Mulyani' ${ }^{1}$ Erick Agustinus ${ }^{2}$ \\ Universitas Pamulang \\ Email: dosen01981@unpam.ac.id ${ }^{1}$, agustinusrick@gmail.com²
}

\begin{abstract}
Purpose. The purpose of this study was to determine the effect of CAR, BOPO, LDR and NIM both partially and simultaneously on Profitability in National Foreign Exchange Public Private Banking Listed on the Indonesia Stock Exchange in 2015-2019.

Methods. The research method used in this research is associative. The population used in this study were 22 national private foreign exchange banks listed on the Indonesia Stock Exchange in 2015-2019. The sample of this research is 11 Public Private National Foreign Exchange Banks. The sampling technique used was purposive sampling. The data analysis method used panel data regression.
\end{abstract}

Findings. The results showed that: Capital adeuency ratio has no effect on profitability. Operating costs of operating income have no effect on profitability. Loan to Deposit Ratio has no effect on profitability. Net interest margin has an effect on profitability. Capital Adeuency Ratio, Operating Costs, Operating Income, Loan to Deposit Ratio, and Net Interest Margin simultaneously affect Profitability of Foreign Exchange National Private Commercial Banks listed on the Indonesia Stock Exchange for the period 2015-2019.

Implication. Investors are expected to consider the Capital Adequacy Ratio, Operational Cost of Operating Income, Loan to Deposit Ratio, and Net Interest Margin before investing their funds in a bank, these four ratios are proven to have a relationship with Profitability.

Keywords. CAR, BOPO, LDR, NIM, ROA.

\begin{abstract}
ABSTRAK
Tujuan. Tujuan penelitian ini adalah untuk mengetahui pengaruh CAR, BOPO, LDR dan NIM baik secara parsial dan secara simultan terhadap Profitabilitas Pada Perbankan Umum Swasta Nasional Devisa Yang Terdaftar di Bursa Efek Indonesia tahun 2015-2019.

Metode. Metode penelitian yang digunakan dalam penelitian adalah Asosiatif. Populasi yang digunakan dalam penelitian ini adalah 22 perbankan umum swasta nasional devisa yang terdaftar di Bursa Efek Indonesia tahun 2015-2019. Sampel penelitian ini adalah 11 pebankan Umum Swasta Nasional Devisa. Teknik pengambilan sampel menggunakan purposive sampling. Teknik analisis data menggunakan regresi data panel.

Hasil. Hasil penelitian menunjukkan bahwa: Capital adeuency ratio tidak berpengaruh terhadap Profitabilitas. Biaya operasional pendapatan operasional tidak berpengaruh terhadap profitabilitas. Loan to Deposit Ratio tidak berpengaruh terhadap profitabilitas. Net interest margin berpengaruh terhadap profitabilitas. Capital Adeuency Ratio, Biaya Operasional Pendapatan Operasional, Loan to Deposit Ratio, dan Net Interest Margin secara simultan berpengaruh terhadap Profitabilitas pada Bank Umum Swasta Nasional Devisa yang terdaftar di Bursa Efek Indonesia periode tahun 2015-2019.
\end{abstract}


Implikasi. Bagi investor diharapkan untuk mempertimbangkan Capital Adequency Ratio, Biaya Operasional Pendapatan Operasional, Loan to Deposit Ratio, dan Net Interest Margin sebelum menginvestasikan dananya pada suatu perbankan keempat rasio tersebut terbukti memiliki hubungan dengan Profitabilitas.

Kata Kunci : CAR, BOPO, LDR, NIM, ROA

\section{Pendahuluan}

Di era modern seperti sekarang, lembaga yang mempunyai peranan strategis dalam kegiatan perekonomian adalah perbankan. Peran strategis tersebut berkaitan erat dengan fungsi utama perbankan sebagai financial intermediary, yaitu sebagai suatu wahana yang dapat menghimpun dan menyalurkan dana masyarakat secara efektif dan efesien. Perbankan sebagai sebuah lembaga yang berfungsi menghimpun dan menyalurkan dana masyarakat pada akhirnya akan memiliki peranan yang strategis untuk mendukung pelaksanaan pembangunan nasional, yakni dalam rangka meningkatkan pemerataan pembangunan dan hasil-hasilnya, pertumbuhan ekonomi dan stabilitas nasional kaearah peningkatan taraf hidup rakyat banyak (Rohayani, 2018:1).

Perkembangan yang pesat pada industri perbankan Bank Umum Swasta Nasional Devisa menyebabkan terjadinya persaingan yang secara langsung maupun tidak langsung berpengaruh terhadap pencapaian profitabilitas bank. Profitabilitas diukur dengan Return On Assets (ROA). Return On Assets (ROA) merupakan salah satu indikator utama dalam penentuan tingkat kesehatan bank, alasan dipilihnya ROA sebagai ukuran kinerja adalah karena ROA dapat digunakan untuk mengukur efektivitas perusahaan didalam menghasilkan keuntungan (laba) dengan memanfaatkan aktiva yang dimilikinya. Profitabilitas dipengaruhi oleh faktor internal dan faktor eksternal. faktor internal terdiri Capital Adequacy Ratio (CAR), Biaya Operasional Terhadap Pendapatan Operasional (BOPO) Loan Deposit Ratio (LDR), dan Net Interest Margin (NIM) sedangkan faktor eksternal terdiri inflasi dan suku bunga.

Tabel 1. Kinerja Keuangan Bank Umum Swasta Nasional Devisa Tahun 2015-2019

\begin{tabular}{|c|c|c|c|c|c|}
\hline Kinerja Keuangan & $\mathbf{2 0 1 5}$ & $\mathbf{2 0 1 6}$ & $\mathbf{2 0 1 7}$ & $\mathbf{2 0 1 8}$ & $\mathbf{2 0 1 9}$ \\
\hline ROA & $124,9 \%$ & $114,8 \%$ & $2,3 \%$ & $1,5 \%$ & $1,4 \%$ \\
\hline CAR & $15,3 \%$ & $70,4 \%$ & $16,4 \%$ & $18,3 \%$ & $1699,6 \%$ \\
\hline BOPO & $71,9 \%$ & $45920,1 \%$ & $67,8 \%$ & $71,4 \%$ & $73,1 \%$ \\
\hline LDR & $128,9 \%$ & $7734,5 \%$ & $84,1 \%$ & $119,3 \%$ & $86,6 \%$ \\
\hline NIM & $9,0 \%$ & $6,4 \%$ & $13,5 \%$ & $5,5 \%$ & $6,0 \%$ \\
\hline
\end{tabular}

Sumber : Data diolah Penulis (2021)

Berdasarkan dari tabel 1 terlihat bahwa jumlah dari rasio keuangan yang dihitung oleh rasio ROA dari periode 2015 hingga periode 2019 memperlihatkan bahwa ROA mengalami penurunan. Sesuai dengan Peringkat Komposit 1 (PK 1) bahwa kinerja bank menurut SE.BI No. 13/24/DPNP/2011 bila ROA sangat sehat adalah > 2\%. Walaupun demikian karena nilai ROA cendrung menurun maka Bank Umum Swasta Nasional Devisa tersebut kurang baik karena profitabilitasnya terus mengalami penurunan.

Nilai CAR pada tahun 2015 sampai dengan tahun 2019 terus menerus mengalami fluktuatif. Di antara perubahan nilai CAR disetiap tahun terdapat fenomena di tahun-tahun tertentu CAR naik dan ROA turun begitupun sebaliknya. Hal ini tidak sesuai dengan teori yang menyatakan apabila CAR naik ROA pun ikut naik. Sesuai dengan Peringkat Komposit 1- PK1 bahwa kinerja bank menurut SE.BI No. 13/24/DPNP/2011 bila CAR sangat sehat adalah > $12 \%$. Disamping itu semakin tinggi nilai CAR maka akan semakin bagus kualitas permodalan bank tersebut.

Untuk perkembangan BOPO dari tahun 2015 - 2019 terus mengalami kenaikan dari tahun 2015 yang hanya 71,9\% menjadi 73,1\% Hal ini menunjukan rata-rata BOPO adalah kurang sehat (sesuai dengan Peringkat Komposit 2 - PK2) bahwa kinerja bank menurut SE.BI No. 13/24/DPNP/2011 bila BOPO cukup sehat adalah 76\% - 93\%. Disamping itu semakin 
rendah nilai BOPO maka akan semakin efisien bank tersebut dan sebaliknya bila nilai BOPO semakin meningkat maka semakin tidak efesien (Biaya Operasional dibandingkan Pendapatan Operasional semakin meningkat).

Selanjutnya Rata-rata LDR Bank Umum Swasta Nasional Devisa mengalami kecenderungan berfluktuasi menurun. Rata-rata LDR pada tahun 2015 sebesar 128,9\%. Pada tahun 2016 rata-rata LDR naik menjadi $7734,5 \%$ dan pada tahun 2019 rata-rata LDR turun menjadi sebesar $86,6 \%$, hal tersebut tidak sesuai dengan teori yang ada bahwa jika LDR naik seharusnya ROA juga ikut naik. Berdasarkan Peraturan Bank Indonesia (PBI) Nomor.12/19/PBI/2010 tanggal 4 Oktober 2010 dan berlaku 1 Maret 2011 Giro Wajib Minimum Bank Umum Pada Bank Indonesia Dalam Rupiah Dan Valuta Asing, tingkat LDR yang dianggap sehat oleh Bank Indonesia adalah berkisar antara 78\% s/d 100\%.

Jika dilihat konsistensi data, nilai rata-rata ROA dan NIM menunjukan adanya inkonsistensi. Di tahun 2016 dan 2018, ROA memiliki hubungan yang tidak konsisten terhadap NIM pada tahun tersebut, dimana ROA mengalami kenaikan sebesar 70,4\%, namun pada saat yang sama NIM mengalami penurunan sebesar 6,4\%. Begitu pula pada tahun 2018, dimana ROA mengalami peningkatan namun NIM menurun. Namun berbeda dengan apa yang terjadi pada hubungan NIM terhadap ROA, pada tahun 2017 ROA mengalami penurunan dan disaat yang sama NIM mengalami kenaikan. Berdasarkan Peraturan Bank Indonesia Nomor 14/26/PBI/2012 tanggal 27 Desember 2012 tentang Kegiatan Usaha dan Jaringan Kantor Berdasarkan Modal Inti Bank, penilaian terhadap NIM sebesar minimal 6\%.

Berdasarkan latar belakang diatas, maka peneliti tertarik untuk mengadakan penelitian dengan judul Analisis Faktor-Faktor Yang Mempengaruhi Profitabilitas Pada Bank Umum Swasta Nasional Devisa Yang Terdaftar Di Bursa Efek Indonesia.

\section{Kajian Pustaka dan Hipotesis}

Return on Asset (ROA). Menurut Kasmir (2016:201) ROA digunakan untuk menunjukkan kemampuan perusahaan menghasilkan laba dengan menggunakan total aset yang dimiliki. Return On Assets (ROA) menunjukkan kemampuan perusahaan dalam menghasilkan laba dari aktiva yang digunakan. ROA merupakan rasio yang terpenting di antara rasio profitabilitas yang ada. Hery (2016:106) mengungkapkan Return On Assets sebagai Hasil pengembalian atas aset (Return On Assets) merupakan rasio yang menunjukkan seberapa besar kontribusi asset dalam menciptakan laba bersih. Sedangkan menurut Sujarweni (2017:65) Return On Assets (ROA) merupakan rasio yang digunakan untuk mengukur kemampuan dari modal yang diinvestasikan dalam keseluruhan aktiva untuk menghasilkan keuntungan neto.

Capital Adequacy Ratio (CAR). CAR menunjukkan besaran jumlah seluruh aset bank yang mengandung resiko, yang dibiayai dari modal bank itu sendiri. Modal terdiri dari Modal Inti dan Modal Pelengkap. Modal inti terdiri dari modal disetor dan cadangan tambahan modal yang terdiri dari faktor penambah (agio, modal sumbangan, cadangan umum modal, cadangan tujuan modal, laba tahun - tahun lalu setelah diperhitungkan pajak, laba tahun berjalan setelah diperhitungkan taksiran pajak (50\%), selisih lebih penjabaran laporan keuangan kantor cabang luar negeri, dan dana setoran modal) dan faktor pengurangan (disagio, rugi tahun tahun lalu, rugi tahun berjalan, selisih kurang penjabaran laporan keuangan kantor cabang diluar negeri, dan penurunan nilai penyertaan pada portofolio yang tersedia untuk dijual). Modal inti juga memperhitungkan faktor berupa goodwill (Willdan, 2014).

Biaya Operasional Terhadap Pendapatan Operasional (BOPO). Menurut ketentuan Bank Indonesia efisiensi operasional perbankan diukur dengan mengunakan rasio biaya operasional dibandingkan dengan pendapatan operasional (BOPO). Melalui BOPO diukur apakah manajemen bank telah menggunakan semua faktor produksinya dengan efektif dan efisien. Mengingat kegiatan utama bank adalah bertindak sebagai perantara, yaitu menghimpun dana dan menyalurkan dana masyarakat, maka biaya dan pendapatan operasional bank didominasi oleh biaya bunga dan hasil bunga (Sudiyatno dan Suroso, 2010). 
Loan to deposit Ratio (LDR). Loan to Deposit Ratio (LDR) menggambarkan besarnya jumlah kredit yang dapat disalurkan kepada masyarakat. Semakin tinggi rasio ini, semakin rendahnya kemampuan likuiditas bank yang bersangkutan, sehingga kemungkinan suatu bank dalam kondisi bermasalah akan semakin besar sehingga dapat dikatakan bahwa bank tersebut tidak menjalankan fungsinya dengan baik (Purwoko dan Sudiyatno, 2013).

Net Interest Margin (NIM). Net Interest Margin (NIM) merupakan perbandingan antara pendapatan bunga bersih terhadap rata-rata aktiva produktif. Purwoko dan Sudiyatno (2013) menyatakan bahwa semakin tinggi NIM menunjukkan semakin efektif bank dalam penempatan aktiva produktif dalam bentuk kredit. Rasio NIM juga digunakan untuk mengukur kemampuan manajemen bank dalam menghasilkan pendapatan bunga dengan melihat kinerja bank dalam menyalurkan kredit, mengingat pendapatan operasional bank sangat bergantung dari selisih bunga dari kredit yang disalurkan.

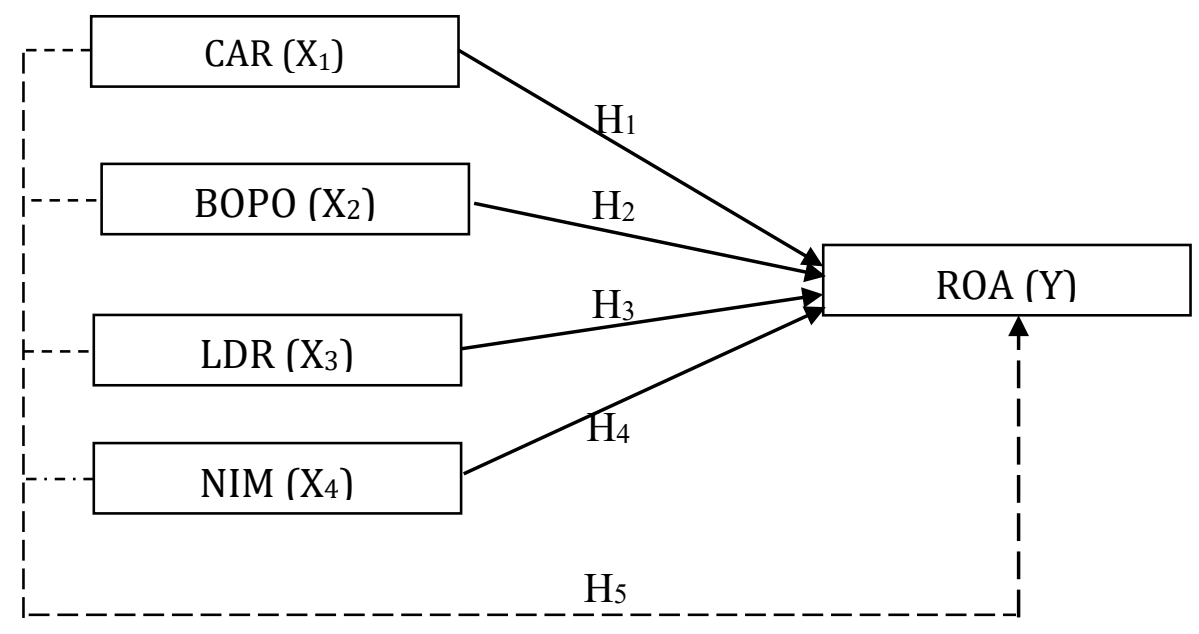

Gambar 1. Model Penelitian

\section{Hipotesis}

H1: Diduga CAR Berpengaruh Terhadap ROA

H2: Diduga BOPO Berpengaruh Terhadap ROA

H3: Diduga LDR Berpengaruh Terhadap ROA

H4 : Diduga NIM Berpengaruh Terhadap ROA

H5 : Diduga CAR, BOLO, LDR dan NIM Berpengaruh Terhadap ROA

\section{Metode Penelitian}

Pendekatan penelitian ini adalah Asosiatif. Menurut Sugiyono (2017) metode Asosiatif bertujuan untuk mengetahui pengaruh atau hubungan antara dua variabel lebih. Penelitian asosiatif mempunyai tingkatan yang lebih tinggi bila dibandingkan dengan deskriptif dan komparitif, lebih lanjut Sugiyono (2017) menjelaskan dengan penelitian Asosiatif maka dibangun suatu teori yang berfungsi untuk menjelaskan, meramalkan dan mengontrol suatu gejala. Jenis data yang digunakan dalam penelitian ini adalah data sekunder, yaitu laporan keuangan Bank Umum Swasta Nasional Devisa yang tercatat di BEI periode 2015-2019 melalui situs resmi BEI yaitu www.idx.co.id.

Populasi dalam penelitian ini adalah Bank Umum Swasta Nasional Devisa yang ada di Indonesia yang terdaftar dalam Bursa Efek Indonesia (BEI) dan Indonesia Stock Exchange (IDX) periode 2015-2019 yaitu berjumlah 22 Bank. Dan jumlah Bank Umum Swasta Nasional Devisa yang ada di Indonesia yang terpilih menjadi sampel penelitian ini adalah 11 perusahaan dikalikan dengan 5 tahun penelitian sehingga jumlah observasi penelitian sebanyak 55 data.

Metode analisis yang dilakukan dalam penelitian ini adalah dengan analisis regresi data panel untuk mengukur pengaruh variabel independen dan variabel dependen yang dinyatakan 
dengan angka-angka yang dalam perhitungannya menggunakan metode statistik yang dibantu dengan program pengolah data statistik yang dikenal dengan EVIEWS 9. Data panel adalah jenis data yang merupakan gabungan dari data time series (runtut waktu) dan cross section (data silang).

\section{Hasil Penelitian dan Pembahasan Statistik Deskriptif}

Tabel 1. Statistik Deskriptif

\begin{tabular}{lccccc}
\hline \hline & ROA & CAR & BOPO & LDR & NIM \\
\hline \hline Mean & 0.487891 & 3.640073 & 92.40856 & 16.30671 & 0.080745 \\
Median & 0.016000 & 0.195000 & 0.720000 & 0.881000 & 0.056000 \\
Maximum & 13.24600 & 180.6220 & 2059.102 & 844.0500 & 0.849000 \\
Minimum & -0.052000 & 0.012000 & 0.463000 & 0.048000 & 0.000000 \\
Std. Dev. & 2.421714 & 24.31217 & 334.4597 & 113.6831 & 0.120457 \\
Skewness & 4.958624 & 7.206873 & 4.380139 & 7.211732 & 5.259722 \\
Kurtosis & 25.63142 & 52.96619 & 23.82461 & 53.01233 & 32.46977 \\
Jarque-Bera & 1399.138 & 6197.529 & 1169.682 & 6208.742 & 2243.831 \\
Probability & 0.000000 & 0.000000 & 0.000000 & 0.000000 & 0.000000 \\
Sum & 26.83400 & 200.2040 & 5082.471 & 896.8690 & 4.441000 \\
Sum Sq. Dev. & 316.6937 & 31918.42 & 6040619. & 697887.9 & 0.783534 \\
Observations & 55 & 55 & 55 & 55 & 55 \\
\hline
\end{tabular}

Sumber: Data diolah Eviews (2021)

Data dari Rerurn On Assets menunjukan nilai maksimum (tertinggi) dari Return On Assets perbankan umum swasta nasional devisa yang menjadi sampel dalam penelitian ini adalah sebesar 13.24600. Nilai minimumnya sebesar -0.052000 , Nilai mean (rata-rata) sebesar 0.487891. sedangkan standar deviasinya sebesar 2.421714. Data dari Capital Adeuency Ratio menunjukan nilai maksimum (tertinggi) dari Capital Adeuency Ratio perbankan umum swasta nasional devisa yang menjadi sampel dalam penelitian ini adalah sebesar 180.6220. Nilai minimumnya sebesar 0.012000 , Niai mean (rata-rata) 3.640073. Sedangkan standar deviasinya sebesar 24.31217.

Data dari Biaya Operasional Pendapatan Operasional menunjukan nilai maksimum (tertinggi) dari Biaya Operasional Pendapatan Operasional perbankan umum swasta nasional devisa yang menjadi sampel dalam penelitian ini adalah sebesar 2059.102. Nilai minimumnya sebesar 0.463000, Nilai mean (rata-rata) sebesar 92.40856. Sedangkan standar deviasinya sebesar 92.40856. Data dari Loan to Deposit Ratio menunjukan nilai maksimum (tertinggi) dari Loan to Deposit Ratio perbankan umum swasta nasional devisa yang menjadi sampel dalam penelitian ini adalah sebesar 844.0500. Nilai minimumnya sebesar 0.048000 , Nilai mean (rata-rata) sebesar 16.30671. sedangkan standar deviasinya sebesar 113.6831.

Data dari Net Inerest Margin menunjukan nilai maksimum (tertinggi) dari Net Interest Margin perbankan umum swasta nasional devisa yang menjadi sampel dalam penelitian ini adalah sebesar 0.849000 . Nilai minimumnya sebesar 0.000000 , Nilai mean (rata-rata) sebesar 0.080745 . sedangkan standar deviasinya sebesar 0.120457 .

\section{Uji Asumsi Klasik \\ Uji Normalitas}

Menurut Ghozali, (2016) bahwa uji normalitas dapat bertujuan untuk menguji apakah model regresi yang digunakan dalam penelitian, variabel dependen, indepen, dan dalam penelitian ini juga di gunakan variabel kontrol memiliki distribusi normal atau tidak. 


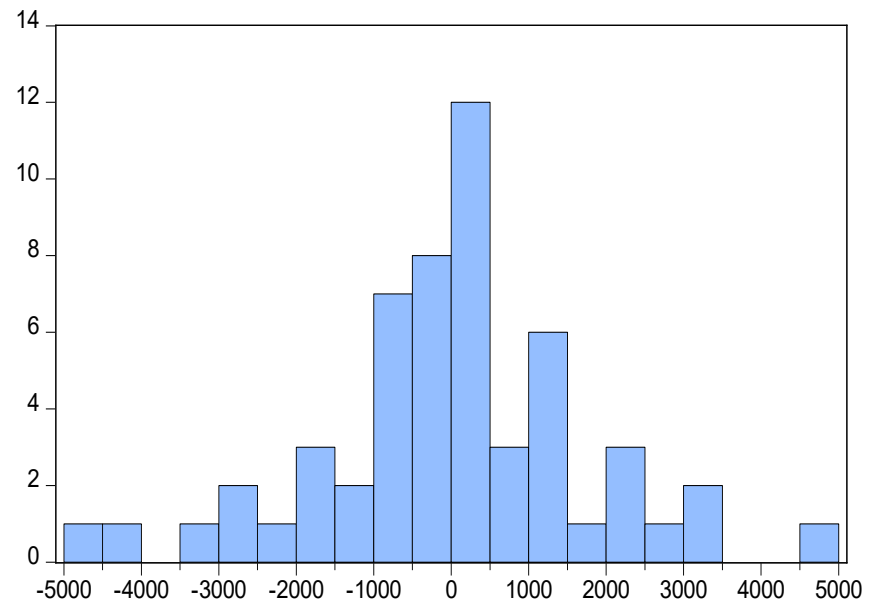

Series: Standardized Residuals

Sample 20152019

Observations 55

Mean $\quad 7.64 \mathrm{e}-12$

Median $\quad 68.94836$

Maximum 4862.595

Minimum $\quad-4667.523$

Std. Dev. $\quad 1727.635$

Skewness $\quad-0.135601$

Kurtosis $\quad 3.980463$

Jarque-Bera 2.371553

Probability $\quad 0.305509$

Gambar 2. Hasil Uji Normalitas

Berdasarkan Gambar 3 menunjukan nilai dari Jarque Bera pada penelitian ini sebesar 2,371553 dengan probability 0,305509 lebih besar dari tingkat signifikansi 0,05. Oleh karena itu penelitian ini berdistribusi normal, sehingga dapat dikatakan persyaratan normalitas dapat terpenuhi.

\section{Uji Multikolineritas}

Menurut Gujarati (2016), jika koefisien korelasi antar variabel bebas $>0,8$ maka dapat disimpulkan bahwa model mengalami masalah multikolinearitas. Sebaliknya, koefisien korelasi $<0,8$ maka model bebas dari multikolinearitas.

Tabel 2. Hasil Uji Multikolineritas

\begin{tabular}{crrrr}
\hline & \multicolumn{1}{c}{ CAR } & \multicolumn{1}{c}{ BOPO } & \multicolumn{1}{c}{ LDR } & \multicolumn{1}{c}{ NIM } \\
\hline \hline CAR & 1.000000 & -0.028944 & -0.019411 & 0.006628 \\
BOPO & -0.028944 & 1.000000 & -0.038754 & -0.011351 \\
LDR & -0.019411 & -0.038754 & 1.000000 & -0.040108 \\
NIM & 0.006628 & -0.011351 & -0.040108 & 1.000000 \\
\hline
\end{tabular}

Sumber: Data diolah Eviews (2021)

Berdasarkan hasil uji multikolinieritas dapat disimpulkan bahwa tidak terdapat multikolinearitas, karena nilai koefisien korelasi antar variabel independen lebih kecil daripada 0,8 .

\section{Uji Heteroskedastisitas}

Tabel 3. Hasil Uji Heteroskedastisitas

\begin{tabular}{lccc}
\hline \hline \multicolumn{1}{c}{ Test } & Statistic & d.f. & Prob. \\
\hline \hline Breusch-Pagan LM & 67.44863 & 55 & 0.1210 \\
Pesaran scaled LM & 1.186931 & & 0.2353 \\
Bias-corrected scaled LM & -0.188069 & & 0.8508 \\
Pesaran CD & -0.356285 & & 0.7216 \\
\hline \hline
\end{tabular}

Sumber: Data diolah Eviews (2021)

Berdasarkan uji Breusch-Pagan di atas, dapat diambil kesimpulan bahwa model regresi tidak terdapat masalah pada uji heteroskedastisitas. Tidak adanya masalah heteroskedastisitas karena nilai probabilitas 0,1210 lebih besar dari 5\%. Dengan demikian, uji Breusch-Pagan menunjukan bahwa hasil regresi tidak mengandung heteroskedastisitas. 


\section{Uji Autokorelasi}

Tabel 4. Hasil Uji Autokorelasi

Breusch-Godfrey Serial Correlation LM Test:

\begin{tabular}{llll}
\hline \hline F-statistic & 0.044454 & Prob. F(2,48) & 0.9566 \\
Obs*R-squared & 0.101685 & Prob. Chi-Square(2) & 0.9504 \\
\hline \hline
\end{tabular}

Sumber: Data diolah Eviews (2021)

Berdasarkan tabel 4 pengujian autokorelasi dengan menggunakan Uji Lagrange Multiplier (LM-test) dapat dilihat bahwa nilai probability Obs*R-squared 0,9504 lebih besar dari 0,05 sehingga dapatdisimpulkan bahwa data dalam variabel penelitian ini tidak terdapat autokorelasi.

\section{Regresi Data Panel}

Dalam penelitian ini menggunakan random effect model dalam menginterprestasikan regresi data panel untuk menjawab penelitian ini.

\section{Tabel 5. Hasil Regresi Data Panel}

Dependent Variable: ROA

Method: Panel EGLS (Cross-section random effects)

Date: 06/08/21 Time: 11:06

Sample: 20152019

Periods included: 5

Cross-sections included: 11

Total panel (balanced) observations: 55

Swamy and Arora estimator of component variances

\begin{tabular}{ccccc}
\hline \hline \multicolumn{1}{c}{ Variable } & Coefficient & Std. Error & t-Statistic & Prob. \\
\hline C & -0.212815 & 0.350729 & -0.606779 & 0.5467 \\
BAR & -0.001206 & 0.009867 & -0.122212 & 0.9032 \\
LDR & -0.000105 & 0.000789 & -0.133332 & 0.8945 \\
NIM & 0.014679 & 0.002110 & 6.955997 & 0.0000 \\
& 5.888262 & 1.980455 & 2.973186 & 0.0045 \\
\hline \hline & Effects Specification & & \\
\hline \hline Cross-section random & & & S.D. & Rho \\
Idiosyncratic random & & & 0.632737 & 0.1227 \\
\hline \hline & & & 1.692284 & 0.8773 \\
\hline \hline R-squared & Weighted Statistics & & \\
Adjusted R-squared & 0.548918 & Mean dependent var & 0.374307 \\
S.E. of regression & 1.628325 & S.D. dependent var & 2.332928 \\
F-statistic & 15.21114 & Durbin-Watson stat & 132.5721 \\
Prob(F-statistic) & 0.000000 & & 1.308739 \\
\hline \hline & Unweighted Statistics & \\
\hline \hline R-squared & 0.542247 & Mean dependent var & 0.487891 \\
Sum squared resid & 144.9675 & Durbin-Watson stat & 1.196836 \\
\hline \hline
\end{tabular}

Sumber: Data diolah Eviews (2021) 
Berdasarkan tabel di atas, maka dapat dikemukakan penjelasan sebagai berikut:

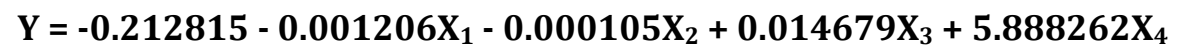

a. Nilai konstanta $(\alpha)$ sebesar -0.212815 yang artinya menunjukkan bahwa jika variabel independen yang terdiri dari Capital Adequency Ratio $\left(\mathrm{X}_{1}\right)$, Biaya Operasional Pendapatan Operasional $\left(\mathrm{X}_{2}\right)$, Loan to Deposit Ratio $\left(\mathrm{X}_{3}\right)$, dan Net Interest Margin $\left(\mathrm{X}_{4}\right)$, dalam keadaan konstan maka nilai variabel Return On Assets sebesar -0.212815.

b. Variabel Capital Adeuency Ratio memiliki nilai koefisien regresi sebesar - 0.001206 dengan tanda negatif, yang berarti setiap kenaikan 1 dari rasio Capital Adequency Ratio, maka nilai Return On ASssets akan turun sebesar - 0.001206 dengan asumsi variabel independen yang lain tetap.

c. Variabel Biaya Operasional Pendapatan Operasional memiliki nilai koefisien regresi sebesar - 0.000105 dengan tanda negatif, yang berarti setiap kenaikan 1 dari rasio Biaya Operasional Pendapatan Operasional, maka nilai Return On Assets akan turun sebesar 0.000105 dengan asumsi variabel independen yang lain tetap.

d. Variabel Loan Depoit Ratio memiliki nilai koefisien regresi sebesar 0.014679 dengan tanda positif, yang berarti setiap kenaikan 1 dari rasio Loan to Deposi Ratio, maka nilai Return On Assets akan naik sebesar 0.014679 dengan asumsi variabel independen yang lain tetap.

e. Variabel Net Interest Margin memiliki nilai koefisien regresi sebesar 5.888262 dengan tanda positif, yang berarti setiap kenaikan 1 dari rasio Net Interest Margin maka nilai Return On Assets akan naik sebesar 5.888262 dengan asumsi variabel independen yang lain tetap.

\section{Uji Hipotesis}

Hipotesis Parsial

Tabel 6. Hasil Uji T Parsial

\begin{tabular}{crrrr}
\hline \hline Variable & Coefficient & Std. Error & t-Statistic & Prob. \\
\hline \hline CAR & -0.001206 & 0.009867 & -0.122212 & 0.9032 \\
BOPO & -0.000105 & 0.000789 & -0.133332 & 0.8945 \\
LDR & 0.014679 & 0.002110 & 6.955997 & 0.0000 \\
NIM & 5.888262 & 1.980455 & 2.973186 & 0.0045 \\
\hline \hline
\end{tabular}

Sumber: Data diolah Eviews (2021)

a. Capital Adeuency Ratio mempunyai nilai signifikansi 0.9032 lebih besar 0,05 maka hipotesis ditolak. Hal ini berarti bahwa variable Capital Adequency Ratio tidak berpengaruh terhadap profitabilitas.

b. Biaya Operasional Pendapatan Operasional mempunyai nilai signifikansi 0.8945 lebih besar 0,05 maka hipotesis kedua ditolak. Hal ini berarti bahwa variable Biaya Operasional Pendapatan Operasional tidak berpengaruh terhadap profitabilitas.

c. Loan to Deposit Raio mempunyai nilai signifikansi 0.0000 lebih kecil 0,05 maka hipotesis ketiga diterima. Hal berarti bahwa variabel Loan to Deposit Ratio berpengaruh terhadap profitabilitas.

d. Net Interest Margin mempunyai nilai signifikasi memiliki nilai signifikansi 0.0045 lebih kecil dari 0,05 maka hipotesis keempat diterima. Hal ini berarti bahwa variabel $\mathrm{Net}$ Interest Margin berpengaruh terhadap profitabilitas.

\section{Hipotesis Simultan}

Untuk menunjukkan apakah semua variabel independen yang dimasukkan dalam model mempunyai pengaruh secara bersama sama terhadap variabel dependen sehingga apakah model dapat digunakan untuk memprediksi variabel dependen maka dilakukanlah uji statistik F sebagai berikut : 
Tabel 7. Hasil Uji F Simultan

\begin{tabular}{llll}
\hline \hline & & & \\
R-squared & 0.548918 & Mean dependent var & 0.374307 \\
Adjusted R-squared & 0.512831 & S.D. dependent var & 2.332928 \\
S.E. of regression & 1.628325 & Sum squared resid & 132.5721 \\
F-statistic & 15.21114 & Durbin-Watson stat & 1.308739 \\
Prob(F-statistic) & 0.000000 & & \\
\hline \hline
\end{tabular}

Sumber: Data diolah Eviews (2021)

Berdasarkan hasil tabel diatas, diketahui bahwa nilai signifikansi lebih kecil dari 0,05, yaitu 0.000000 maka hipotesis ke lima diterima. Hal ini berarti terdapat pengaruh secara simultan antara variabel Capital Adeuency Ratio, Biaya Operasional Pendapatan Operasional, Loan to Deposit Ratio, dan Net Interest Margin terhadap Profitabilitas.

\section{Koefisien Determinasi $\left(\mathbf{R}^{2}\right)$}

Berdasarkan Tabel 7, nilai koefisien determinasi R-squared sebesar 0.548918. Nilai tersebut berarti seluruh variabel bebas, yaitu Capital Adeuency Ratio Biaya Operasional Pendapatan Operasional, Loan to Deposit Ratio, dan Net Interest Margin, secara simultan mempengaruhi variabel Profitabilitas sebesar 54,89\%, sisanya sebesar 46,11\% dipengaruhi oleh faktor lain yang tidak bisa dijelaskan dalam penelitian ini

\section{Pembahasan}

\section{Pengaruh CAR Terhadap ROA}

Berdasarkan hasil penelitian menunjukkan bahwa Capital Adeuency Ratio mempunyai nilai signifikansi lebih besar dari 0,05 yaitu sebesar 0.9032 hipotesis pertama ditolak. Hal ini berarti bahwa variabel Capital Adequency Ratio tidak berpengaruh terhadap profitabilitas pada perbankan umum swasta nasional devisa yang terdaftar di Bursa Efek Indonesia periode 20152019. Dalam penelitian ini menunjukkan bahwa besarnya Capital Adeuency Ratio tidak mempengaruhi Profitabilitas dikarenakan setiap kenaikan Capital Adeuency Ratio akan menurunkan nilai Profitabilitas.

Hasil penelitian ini sejalan dengan penelitian yang dilakukan oleh Dewi (2018) yang menyatakkan bahwa CAR tidak memiliki pengaruh positif secara parsial terhadap profitabilitas. Namun penelitian tersebut tidak sejalan dengan penelitian yang dilakukan Mario Christiano, Parengkua Tommy Ivon Serang (2014) dalam penelitiannya menghasilkan bahwa Capital Adeuency Ratio berpengaruh positif dan signifikan terhadap profitabilitas.

\section{Pengaruh BOPO Terhadap ROA}

Berdasarkan hasil penelitian menunjukkan bahwa Biaya Operasional pendapatan Operasional mempunyai nilai signifikansi lebih besar dari 0,05 yaitu sebesar 0.8945, maka hipotesis kedua ditolak. Hal ini dapat disimpulkan bahwa Biaya Operasional Pendapatan Operasional tidak berpengaruh terhadap Profitabilitas perbankan umum swasta nasional devisa yang terdaftar di Bursa Efek Indonesia periode tahun 2015-2019.

Hasil penelitian ini tidak sejalan dengan penelitian terdahulu yang dilakukan oleh Anissa (2014) yang menyatakkan bahwa BOPO secara parsial memiliki pengaruh Positif Terhadap profitabilitas. Tetapi penilitian ini sejalan dengan penelitian yang dilakukan oleh Wibowo dan Syaichu (2013) bahwa BOPO memiliki pengaruh negatif terhadap Profitabilitas (ROA).

\section{Pengaruh LDR Terhadap ROA}

Berdasarkan hasil penelitian menunjukkan bahwa Loan to Deposit Ratio mempunyai nilai signifikansi lebih kecil dari 0,05 yaitu sebesar 0.0000 , maka hipotesis ketiga diterima. Hal ini dapat disimpulkan bahwa Loan to Deposit Ratio berpengaruh terhadap profitabilitas pada perbankan umum swasta nasional devisa yang terdaftar di Bursa Efek Indonesia periode tahun 2015-2019.

Penelitian ini sejalan dengan penelitian yang dilakukan oleh Dewi (2017), LDR mempunyai pengaruh positif yang signifikan terhadap ROA. Kemudian penelitian Astohar 
(2018) LDR terbukti mempunyai pengaruh yang negatif dan signifikan terhadap ROA. Serta penelitian Handayani, Mardani dan Khoirul (2019) LDR berpengaruh positif dan tidak signifikan terhadap ROA.

\section{Pengaruh NIM Terhadap ROA}

Berdasarkan hasil penelitian menunjukkan bahwa Net Interest Margin mempunyai nilai signifikansi lebih kecil dari 0,05 yaitu sebesar 0.0045, maka hipotesis keempat diterima. Sehingga disimpulkan Net Interest Margin berpengaruh terhadap profitabilitas pada perbankan umum swasta nasional devisa yang terdaftar di Bursa Efek Indonesia periode tahun 2015-2019.

Penelitian ini sejalan dengan penelitian yang dilakukan oleh Handayani, Mardani dan Khoirul (2019) NIM berpengaruh positif dan signifikan terhadap ROA. Dewi (2017) menyatakan NIM mempunyai pengaruh negatif yang tidak signifikan terhadap ROA. Serta penelitian Astohar (2018) NIM terbukti mempunyai pengaruh yang positif dan signifikan terhadap ROA.

\section{Pengaruh CAR, BOPO, LDR dan NIM Terhadap ROA}

Berdasarkan Uji Simultan F menunjukkan bahwa Capital Adeuency Ratio, Biaya Operasional Pendapatan Operasional, Loan to Deposit Ratio, dan Net Interest Margin secara simultan diperoleh nilai signifikansi lebih kecil dari 0,05, yaitu sebesar 0,000. Sehingga dapat disimpulkan bahwa Capital Adeuency Ratio, Biaya Operasional Pendapatan Operasional, Loan to Deposit Ratio, dan Net Interest Margin secara simultan berpengaruh terhadap Profitabilitas pada perbankan umum swasta nasional devisa yang terdaftar di Bursa Efek Indonesia tahun 2015-2019. Dengan demikian H5 diterima.

Penelitian ini sejalan dengan penelitian yang dilakukan oleh Witiastuti dan Khaerudin (2014) CAR, LDR, dan Inflasi berpengaruh positif tetapi tidak signifikan terhadap ROA. Munir (2018) CAR, NPF, FDR dan inflasi secara simultan berpengaruh signifikan terhadap variabel dependen ROA. Penelitian Welta dan Lemiyana (2017) juga menyatakan Secara simultan CAR, Inflasi dan Nilai Tukar mempunyai pengaruh terhadap ROA.

\section{Kesimpulan}

Berdasarkan hasil penelitian dan pembahasan di bab-bab sebelumnya maka diperoleh kesimpulan bahwa: Capital Adeuency Ratio tidak berpengaruh terhadap Profitabilitas pada Bank Umum Swasta Nasional Devisa yang terdaftar di Bursa Efek Indonesia periode tahun 2015-2019. Biaya Operasional Pendapatan Operasional tidak berpengaruh terhadap Profitabilitas pada Bank Umum Swasta Nasional Devisa yang terdaftar di Bursa Efek Indonesia periode tahun 2015-2019. Loan to Deposit Ratio tidak berpengaruh terhadap Profitabilitas pada Bank Umum Swasta Nasional Devisa yang terdaftar di Bursa Efek Indonesia periode tahun 2015-2019. Net Interest Margin berpengaruh terhadap Profitabilitas pada Bank Umum Swasta Nasional Devisa yang terdaftar di Bursa Efek Indonesia periode tahun 2015-2019. Capital Adeuency Ratio, Biaya Operasional Pendapatan Operasional, Loan to Deposit Ratio, dan Net Interest Margin secara simultan berpengaruh terhadap Profitabilitas pada Bank Umum Swasta Nasional Devisa yang terdaftar di Bursa Efek Indonesia periode tahun 2015-2019.

\section{Daftar Pustaka}

Aini, N. (2013). Pengaruh CAR, NIM, LDR, NPL, BOPO, dan Kualitas Aktiva Produktif Terhadap Perubahan Laba (Studi Empiris Pada Perusahaan Perbankan yang terdaftar di BEI) Tahun 2009-2011. Dinamika Akuntansi, Keuangan dan Perbankan, 2(1), 14 - 25.

Amelia, W., \& Hernawati, E. (2016). Pengaruh Komisaris Independen, Ukuran Perusahaan dan Profitabilitas Terhadap Manajemen Laba. NeO Bis, 63.

Arlin, P. A., \& Suwarno, E. (2016). Pengaruh Capital Adequacy Ratio (CAR), Loan To Deposit Ratio (LDR), dan Perbandingan Biaya Operasional Dengan Pendapatan Operasional (BOPO) Terhadap Return On Assets (ROA) (Studi Empiris pada 3 Bank Persero Terbesar 
di Indonesia Periode 2010-2014). Doctoral dissertation. Universitas Muhammadiyah Surakarta.

Astohar, A. (2019). Analisis Faktor - Faktor Yang Berpengaruh Terhadap Profitabilitas Perbankan Yang Go Public Di Bursa Efek Indonesia Pada Tahun 2012-2016. Jurnal Dinamika Ekonomi \& Bisnis, 15(1), 1-14. https://doi.org/10.34001/jdeb.v15i1.913

Christiano, M., Tommy, P., \& Saerang, I (2014). Analisis Terhadap Rasio-Rasio Keuangan Keuangan Untuk Mengukur Profitabilitas Pada Bank-Bank Swast Yang Go Public Di Bursa Efek Indonesia. Jurnal EMBA, 2(4), 817-830.

Darmansyah. (2014). Capital Adequacy Ratio, Loan To Deposit Ratio, Non Performing Loan, Operational Cost Ratio, Net Interest Margin dan Return On Assets Perusahaan Perbankan. Jurnal Riset Akuntansi dan Perpajakan (JRAP), 1(1), 82 - 94.

Dendawijaya, L. (2009). Manajemen Perbankan. Jakarta: Ghalia Indonesia.

Dewi, I. K., dan Solihin, D. (2020). Pengaruh Current Ratio Dan Net Profit Margin Terhadap Harga Saham Pada Perusahaan Makanan Dan Minuman Yang Terdaftar Di Bursa Efek Indonesia (BEI) Periode 2015-2018. JURNAL ILMIAH FEASIBLE: Bisnis, Kewirausahaan \& Koperasi 2 (2), 183-191.

Dewi, L. E., Herawati, N. T., \& Sulindawati, L. G. E. (2015). Analisis Pengaruh NIM, BOPO, LDR, dan NPL terhadap Profitabilitas (Studi Kasus Pada Bank Umum Swasta Nasional Yang Terdaftar Pada Bursa Efek Indonesia Periode 2009 - 2013). E-Journal Jurusan Akuntansi Program S1 Universitas Pendidikan Ganesha, 3(1).

Dewi, A. S. (2017). Pengaruh CAR, BOPO, NPL, NIM, Dan LDR Terhadap ROA Pada Perusahaan Di Sektor Perbankan Yang Terdaftar Di Bei Periode 2012-2016. Jurnal Pundi, 01(03), 223-236.

Dharmayanti, P. E. P., Purnamawati, I. G. A., \& Edy Sujana, S. E. (2016). Pengaruh Faktor Keuangan Dan Fundamental Perekonomian Makro Terhadap Profitabilitas Sektor Perbankan (Studi Empiris pada Bank Umum Swasta Nasional Devisa yang Listing di Bursa Efek Indonesia periode 2010-2014). JIMAT (Jurnal Imiah Mahasiswa Akuntansi) Undiksha, 3(1).

Fadjar. (2017). Analisis Faktor Internal dan Eksternal Bank yang Mempengaruhi Profitabilitas Bank Umum di Indonesia. Journal of Management and Business Review, 10(1).

Fahmi, I. (2015). Pengantar Manajemen Keuangan Teori dan Soal Jawab. Bandung: Alfabeta.

Fajari S, Sunarto. (2017). Pengaruh CAR, LDR, NPL, BOPO terhadap profitabilitas bank (studi kasus perusahaan perbankan yang tercatat di Bursa Efek Indonesia periode tahun 2011 sampai 2015). Prosiding Seminar Nasional Multi Disiplin Ilmu \&Call For Papers Unisbank Ke-3 (Sendi_U 3). Unisbank, P. 853-862.

Fauziah, H. (2021). Pengaruh NPL, CAR, dan BI Rate terhadap ROA pada Bank Badan Usaha Milik Negara. Indonesian Journal of Economics and Management, 1(2), 352-365.

Ghozali. (2016). Aplikasi Analisis Multivariete Dengan Program IBM SPSS. Semarang: Badan Penerbit Universitas Diponegoro.

Gujarati, D. N. (2016). Dasar-Dasar Ekonometrika. Buku II. Edisi. Kelima. Jakarta Selatan: Salemba Empat.

Hery. (2016). Analisis Laporan Keuangan. Jakarta: Grasindo.

Husein, F. M. (2017). Pengaruh CAR, BOPO, NPL Dan LDR Terhadap ROA Pada Bank Konvensional Di Indonesia. Jurnal Administrasi Bisnis, 5(40), pp. 1229-1240. 
Indriasari. (2016). Pengaruh CAR, NPL, Dan LDR Terhadap Kinerja Keuangan pada Perusahaan Sektor Perbankan Yang Terdaftar di BEI Tahun 2013-2015. Skripsi. Fakultas Ekonomi dan Bisnis Islam Institut Agama Islam Negeri. Surakarta

Julaeha. (2015). Pengaruh Non Performing Loan, Net Interest Margin, Biaya Operasional/Pendapatan Operasional Dan Loan To Deposit Ratio Terhadap Profitabilitas Bank(Studi Kasus Bank Rakyat Indonesia, Tbk Periode 2003 - 2014). Jurnal Ekonomi Bisnis Volume, 20(3).

Kasmir. (2016). Analisis Laporan Keuangan. Jakarta: Raja Grafindo Persada.

Laksono, F. D., \& Mu'id, D. (2014). Analisis Faktor-Faktor yang Mempengaruhi Audit Delay dan Ketepatan Waktu Publikasi Laporan Keuangan (Studi Empiris Pada Perusahaan Manufaktur Sektor Consumer Good Yang Terdaftar di Bei Tahun 2010 - 2012). 3(4), 113.

Likahandayani, Mardani, R. M., \& Abs, M. K. (2017). Analisis Faktor-Faktor Yang Mempengaruhi Profitabilitas Perbankan Pada Bank Umum Go Public Yang Terdaftar Di Bursa Efek Indonesia (Bei) Periode Tahun 2015-2017. E - Jurnal Riset Manajemenprodi Manajemen Fakultas Ekonomi Unisma, 2(1), 62-74.

Mawardi, W. (2005). Analisis Faktor-Faktor yang Mempengaruhi Kinerja Keuangan Bank Umum di Indonesia. Jurnal Bisnis Strategi 14(1).

Munir, M. (2018). Analisis Pengaruh CAR, NPF, FDR dan Inflasi terhadap Profitabilitas Perbankan Syariah di Indonesia. Ihtifaz: Journal of Islamic Economics, Finance, and Banking, 1(1), 89-98. https://doi.org/10.12928/ijiefb.v1i1.285

Purwoko, D., \& Sudiyatno, B. (2013). Faktor-Faktor yang Mempengaruhi Kinerja Bank (Studi Empirik Pada Industri Perbankan di Bursa Efek Indonesia), Jurnal Bisnis dan Ekonomi (JBE). 20(1).

Putri, I. G. A. M. K., Kepramareni, P., \& Oka, P. (2021). Pengaruh Capital Adequacy Ratio, NonPerforming Loan, Loan To Deposit Ratio, Biaya Operasional, Pendapatan Operasional, Tingkat Suku Bunga BI Terhadap Profitabilitas Perusahaan. Jurnal Kharisma, 3(1), 207-218.

Rachmawati, S., \& Marwansyah, S. (2019). Pengaruh Inflasi, Bi Rate, CAR, NPL, BOPO Terhadap Profitabilitas Pada Bank BUMN. Jurnal Mantik, 3(1) pp. 117-122.

Rohayani (2018) Pengaruh Net Interest Margin (NIM), Biaya Operasional Pendapatan Operasional (BOPO) dan Dana Pihak Ketiga (DPK) terhadap Return On Assets (ROA) Pada Bank Negara Indonesia (BNI) Periode 2011-2019.http://digikib.uinsgd.ac.id/12135

Ross, S. A. (1977). The Determination of Financial Structure: The Incentive Signaling Approach. Bell Journal of Economics and Management Science, 8 (1): 23-40.

Saputra, A., Arfan, M., \& Saputra, M. (2018). Pengaruh Capital Adequacy Ratio, Net Interest Margin, Loan To Deposit Ratio Dan Non Performing Loan Terhadap Profitabilitas Bank Umum Non Devisa Di Indonesia Periode 2014-2016. Jurnal Perspektif Ekonomi Darussalam, 4(2).

Saryani, D. (2015). Analisis Capital Adequacy Ratio, Non Performing Loan, Net Interest Margin, Biaya Operasional, Loan to Deposit Ratio, Ukuran Perusahaan terhadap Profitabilitas Bank Umum di Indonesia yang Terdaftar pada Bursa Efek Indonesia. Journal of Accounting, 1(1).

Setiawan, S. (2018). Pengaruh CAR, BOPO, NPL, Inflasi Dan Suku Bunga Terhadap Profitabilitas Pada Bank Umum Konvensional Yang Terdaftar Di Bursa Efek Indonesia. Media Manajemen Jasa, 6(2), 1-17. 
Shafrani, Y. S., \& Lestari, A. D. (2020). Pengaruh Npf, Car, Bopo, Inflasi Dan Kurs Rupiah Terhadap Return On Assets (Studi Kasus Pt Bank Muamalat Indonesia, Tbk. Periode 2015-2019). Indonesian Journal of Islamic Business and Economics, 02(01), 14-29.

Sintiya, S. (2018). Analisis Pengaruh BOPO, FDR dan CAR terhadap Profitabilitas Bank Umum Syariah Periode 2012-2016 (Studi Kasus pada Bank Umum Syariah di di Indonesia Periode 2012-2016). Other thesis, IAIN SALATIGA.

Spence, Michael. (1973). Job Market Signaling. The Quarterly Journal of Economics, 87(3) pp. 355-374. The MIT Press.

Solihin, D. (2019), Pengaruh Current Ratio dan Debt To Equity Ratio Terhadap Return On Asset (ROA) Pada PT Kalbe Farma, Tbk. KREATIF: Jurnal Ilmiah Prodi Manajemen Universitas Pamulang 7 (1), 115-122.

Sudarini, S. (2005), Penggunaan Rasio Keuangan Dalam Memprediksi Laba pada Masa Yang Akan Datang, Jurnal Akuntansi dan Manajemen, XVI(3).

Sudarmawanti E, Pramono J. (2017).Pengaruh CAR, NPL, BOPO, NIM dan LDR terhadap ROA: studi kasus pada Bank Perkreditan Rakyat di Salatiga yang terdaftar di Otoritas Jasa Keuangan tahun 2011- 2015. Among Makarti, 10(19): 1-18.

Sudiyatno, B., \& Suroso, J. (2010). Analisis Pengaruh Dana Pihak Ketiga, Bopo, Car Dan Ldr Terhadap Kinerja Keuangan Pada Sektor Perbankan Yang Go Public Di Bursa Efek Indonesia (BEI) (Periode 2005-2008). Dinamika Keuangan dan Perbankan. 2(2).

Sugiyono. (2017). Metode Penelitian Kuantitatif, Kualitatif, dan R\&D. Bandung: Alvabeta.

Sujarweni, V. W. (2017). Analisis Laporan Keuangan: Teori, Aplikasi, \& Hasil Penelitian. Yogyakarta: Pustaka Baru Press.

Sutami, P. S. (2020). Pengaruh Tingkat Perputaran Kas, Loan to Deposit Ratio, Capital Adequacy Ratio dan BOPO Terhadap Profitabilitas pada Koperasi Simpan Pinjam Di Kabupaten Badung Tahun 2016-2018. Skripsi. FEB Universitas Mahasarasati Denpasar.

Taswan. (2010). Manajemen Perbankan, Konsep, Teknik, dan Aplikasi. Edisi. Kedua. Yogyakarta: UPP STIM YKPN.

Welta, F. (2017). Pengaruh Car, Inflasi, Nilai Tukar Terhadap Profitabilitas Pada Bank Umum Syariah. I-Finance, 1(1), 85-100.

Wibowo, E.S., \& Syaichu, M. (2013). Analisis Pengaruh Suku Bunga, Inflasi, CAR, BOPO, NPF terhadap Profitabilitas. Dipenogoro Journal Of Accounting, 2(2).

Widyastuti, T., \& Octaviani, Y. R. (2010). Pengaruh CAR, NIM dan LDR terhadap ROA pada Perusahaan Perbankanyang Terdaftar di BEI selama tahun 2004 - 2008. Jurnal Akuntansi Keuangan, 10(1).

Winarno, W.W. (2015). Analisis Ekonometrika dan Statistika dengan Eviews, Edisi empat. Yogyakarta: UPP STIM YKPN.

Witiastuti, R. S. (2014). Kajian Pengaruh CAR, NPL, LDR, BOPO, Inflasi, Dan Suku Bunga BI Terhadap Kinerja Keuangan Sektor Perbankan Di Bursa Efek Indonesia. WAHANA, 17(2), 111-120.

Yustika. (2015). Pengaruh Likuiditas, Leverage, Profitabilitas, Operating Capacity Dan Biaya Agensi Manajerial Terhadap Financial Distress. Jurnal Online Mahasiswa Universitas Riau. 2(2). 